\title{
Sensitivity of the Ross Ice Shelf to environmental and glaciological controls
}

Francesca Baldacchino $^{1}$, Mathieu Morlighem ${ }^{2,3}$, Nicholas R. Golledge ${ }^{1}$, Huw Horgan ${ }^{1}$, and Alena Malyarenko ${ }^{4,1}$

${ }^{1}$ Antarctic Research Centre,Victoria University of Wellington, New Zealand

${ }^{2}$ Department of Earth Sciences,Dartmouth College, Hanover, NH 03755, USA

${ }^{3}$ Department of Earth System Science, University of California Irvine, Irvine, CA 92697, USA

${ }^{4}$ National Institute of Water and Atmosphere Research, Wellington, New Zealand

Correspondence: Francesca Baldacchino (francesca.baldacchino@vuw.ac.nz)

\begin{abstract}
The Ross Ice Shelf (RIS) is currently stable but recent observations have indicated that basal melt rates beneath the ice shelf are expected to increase. It is important to know which areas of the RIS are more sensitive to enhanced basal melting as well as other external forcings or internal material properties of the ice to understand how climate change will influence RIS mass balance. In this paper, we use Automatic Differentiation and the Ice Sheet and Sea-level System Model to quantify the sensitivity of the RIS to changes in basal friction, ice rigidity, surface mass balance, and basal melting. Using Volume Above Flotation (VAF) as our quantity of interest, we find that the RIS is most sensitive to changes in basal friction and ice rigidity close to grounding lines and along shear margins of the Siple Coast Ice Streams and Transantarctic Mountains Outlet Glaciers. RIS sensitivity to surface mass balance is uniform over grounded ice, while the sensitivity to basal melting is more spatially variable. With changes in basal melting close to the grounding zones of the Siple Coast Ice Streams and Transantarctic Mountains Outlet Glaciers as well as the pinning points of the RIS including Ross Island, Roosevelt Island, Crary Ice Rise, Steershead Ice Rise and the Shirase Coast Ice Rumples and the ice shelf shear margins having a larger impact on the RIS VAF. Our sensitivity maps allow areas of greatest future vulnerability to be identified.
\end{abstract}

\section{Introduction}

Understanding and predicting how ice sheets will evolve in a warming world has become one of the most important questions for future climate change. An increase of 1.5 to $2^{\circ} \mathrm{C}$ in global temperature could lead to multi-meter rise in global sea-level over the next 100 to 1000 years (Raftery et al., 2017; Pattyn, 2018; Jenkins et al., 2018; Golledge et al., 2019). The Antarctic Ice Sheet (AIS) holds 91 percent of the global ice and consequently is the largest potential contributor to global sea level rise (Dirscherl et al., 2020; Mottram et al., 2020). AIS mass loss has accelerated over the past several decades primarily due to the intrusion of warm Circumpolar Deep Water (CDW) in ice shelf cavities in the Amundsen Sea Embayment, which has increased ice discharge into the ocean (Shepherd et al., 2012, 2018; Rignot et al., 2019).

Ice shelves along Antarctica's coast play a fundamental role in controlling mass flux because they buttress the outflow of mass by reducing longitudinal stresses at the grounding line (Schoof, 2007; Gudmundsson, 2013; Pattyn and Durand, 2013). 
https://doi.org/10.5194/tc-2022-50

Preprint. Discussion started: 3 March 2022

(c) Author(s) 2022. CC BY 4.0 License.

\section{(c) (i)}

Recently, most of the mass loss from ice shelves has been through ocean-forced basal melting (Pritchard et al., 2012; Jenkins et al., 2018; Pattyn, 2018; Rignot et al., 2019; Robel et al., 2019). Ocean-forced basal melting reduces the buttressing effect of ice shelves by thinning them and allowing their velocity to increase. This causes greater discharge across the grounding line, and subsequent grounding line retreat (Moholdt et al., 2014; Pattyn et al., 2017; Shepherd et al., 2018; Gudmundsson et al., 2019).

The Ross Ice Shelf (RIS) is the largest cold-water ice shelf in Antarctica, buttressing both the West Antarctic Ice Sheet (WAIS) and the East Antarctic Ice Sheet (EAIS). Through the ice shelf restraining this ice in the catchment, it has a total potential contribution to sea level rise of $11.6 \mathrm{~m}$ (Tinto et al., 2019). The stability of WAIS is a major uncertainty in predicting the AIS's future contribution to sea level rise (Pattyn and Durand, 2013; Jenkins et al., 2018). Recent research has indicated that a tipping point may have already been passed in some sectors of WAIS, causing irreversible grounding line retreat and thinning (Rignot et al., 2014; Golledge et al., 2019; Robel et al., 2019).

The RIS is currently stable, as its sub-ice shelf cavity has been insulated from inflows of warm CDW (Dinniman et al., 2011; Tinto et al., 2019; Das et al., 2020). Instead, basal mass loss is driven by subsurface inflows of cold, high salinity shelf water that melts ice near the grounding lines, and by seasonal inflows of summer-warmed Antarctic Surface Water (ASW) that melts shallow ice along the ice shelf front (Assmann et al., 2003; Stern et al., 2013; Stewart et al., 2019; Tinto et al., 2019; Adusumilli et al., 2020). These two different ocean processes cause basal melting, and thus mass loss on the RIS, to be variable in both space and time (Adusumilli et al., 2020). For example, basal melt rates exceeding $10 \mathrm{~m} \mathrm{a}^{-1}$ have been found at the grounding line of Byrd Glacier (Kenneally and Hughes, 2004), while annual-averaged rates on the order of $1 \mathrm{~m} \mathrm{a}^{-1}$ have been reported along the ice shelf front (Horgan et al., 2011; Moholdt et al., 2014; Stewart et al., 2019). Additionally, elevated basal melt rates of $10 \mathrm{~m} \mathrm{a}^{-1}$ on the ice shelf front near Ross Island have been observed in recent years due to intrusions of seasonal warm ASW (Stewart et al., 2019; Tinto et al., 2019; Das et al., 2020; Adusumilli et al., 2020). Previous modelling studies have found that ice shelf thinning at Ross Island, could have a substantial impact on ice dynamics over a large region, including grounded ice up to $1000 \mathrm{~km}$ away at the WAIS grounding line of RIS (Fürst et al., 2016; Reese et al., 2018; Gudmundsson et al., 2019; Klein et al., 2020). However, averaged over the entire ice shelf, basal melt rates remain low, on the order of $0.1 \mathrm{~m} \mathrm{a}^{-1}$ (Rignot et al., 2013; Moholdt et al., 2014; Adusumilli et al., 2020) due to the low temperature of water masses on the Ross Sea continental shelf (Pritchard et al., 2012). Basal melt rates are expected to increase with predicted surface warming potentially impacting the future stability of the RIS (Schodlok et al., 2016; Stewart et al., 2019).

It remains unclear whether changes in external forcings (such as basal melting and surface mass balance) or other processes (such as the internal material properties of the ice) could cause more mass loss in the future and where on the RIS this mass loss could occur. Moreover, glaciers and ice sheets can respond differently to different melt rates distributions even when the total integrated melt is the same (Gagliardini et al., 2010). Hence, the spatial pattern of melt rates has a stronger impact than the area-averaged value of basal melt. In addition, it has been shown that basal melting at the grounding line causes increased grounding line retreat, indicating that knowledge of basal melt distribution is critical for accurate prediction of grounding line migration (Walker et al., 2008). 
This paper investigates which changes in external forcings and internal material properties of the ice have the largest effect on the overall mass balance of the system and identifies areas of sensitivity on the RIS. The external forcings investigated are ocean-forced melt rates and surface mass balance. The internal material properties we investigate here are ice rigidity and basal friction. These four properties are chosen as they each have the potential to enhance ice discharge and Volume Above Flotation (VAF) of the RIS (Shepherd et al., 2012, 2018; Rignot et al., 2019). These parameters are explored using the Automatic Differentiation (AD, M. Sagebaum, 2019) tool in the Ice-sheet and Sea-level System Model (ISSM). The AD tool produces a spatial map identifying where, and how sensitive, VAF is to parameter changes. VAF is calculated for the entire domain, while the sensitivity is specific to the location concerned.

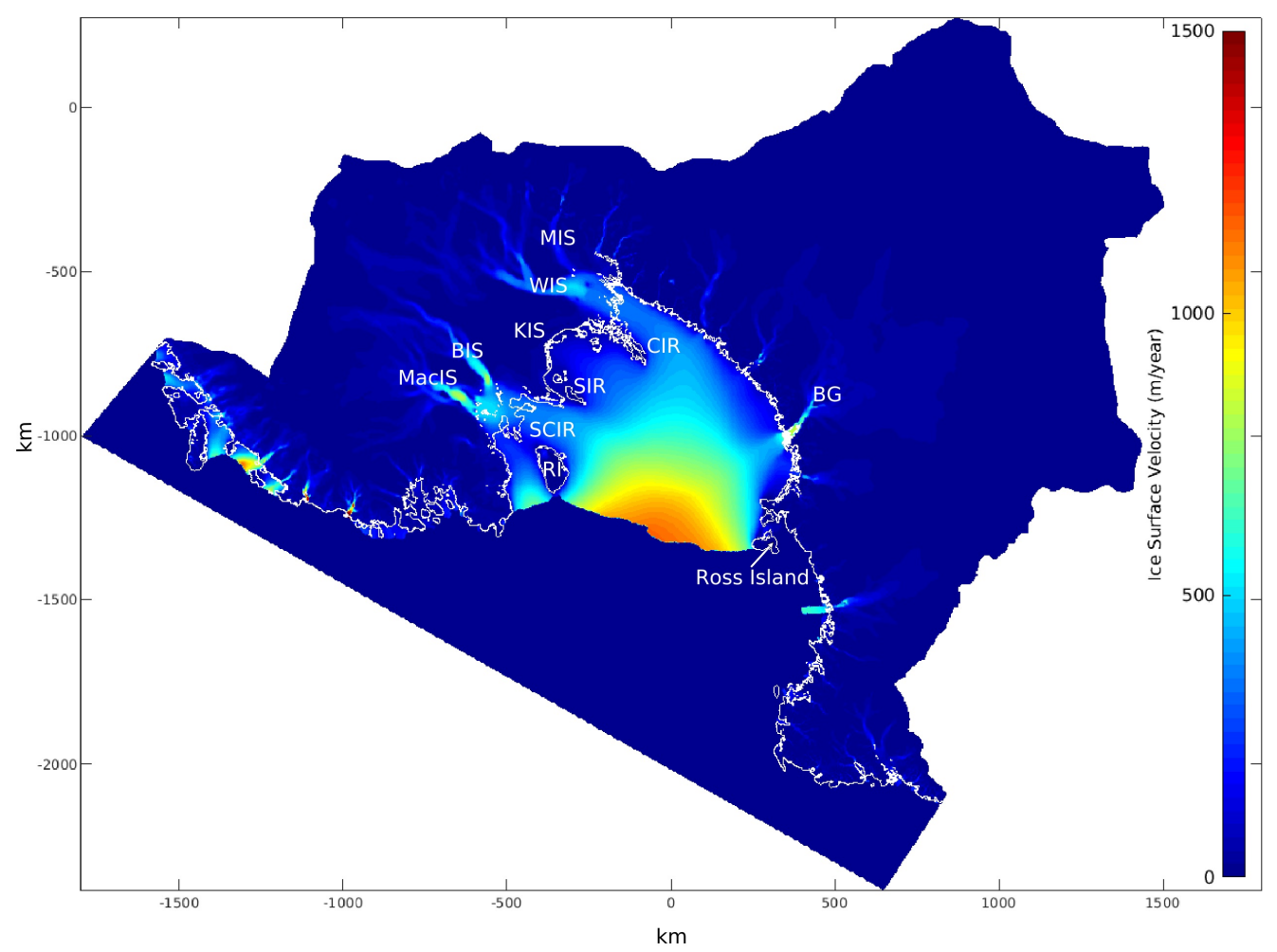

Figure 1. Modelled Ross Ice Shelf surface velocities after initialisation. The grounding line is marked in white. Locations discussed in this paper are labelled. These include the Siple Coast Ice Streams: Mercer Ice Stream (MIS), Whillans Ice Stream (WIS), Kamb Ice Stream (KIS), Bindschadler Ice Stream (BIS) and MacAyeal Ice Stream (MacIS). Byrd Glacier (BG) and Ross Island are also labelled. In addition, the ice rises are labeled on the Siple Coast: CIR = Crary Ice Rise, SIR = Steershead Ice Rise, SCIR = Shirase Coast Ice Rumples and RI = Roosevelt Island. 
We here use the Ice-sheet and Sea-level System Model (ISSM) to explore the influence that changes in the chosen parameters have on the mass balance of the model domain. We use a Shallow Shelf approximation (SSA, (MacAyeal, 1989)) with a rheology based on Glen's flow law (Glen, 1955) and ice viscosity depending on the ice temperature (Cuffey and Paterson, 2010). The basal friction is based on a Budd friction law (Budd et al., 1979) and the grounding line evolves assuming hydrostatic equilibrium following a sub-element grid scheme (Seroussi et al., 2014). The ice front remains fixed through time during all the simulations performed.

The model domain covers the entire RIS and its tributaries as observed today (Zwally et al., 2012) (Figure 1). Ice thickness and bed elevation are interpolated from the BedMachine v2 dataset (Morlighem and Binder, 2020). Our simulations rely on a non-uniform mesh that has a resolution of $1 \mathrm{~km}$ at the grounding lines and in the shear margins, increasing to $20 \mathrm{~km}$ in the ice sheet interior, and with a nominal resolution of $10 \mathrm{~km}$ within the ice shelf. The basal friction coefficient is inferred through a data assimilation technique (Morlighem et al., 2013) to reproduce observed InSAR surface velocities from the MEaSURES data-set (Rignot et al., 2017). Environmental boundary conditions include RACMO surface mass balance (Lenaerts et al., 2012) and basal melt rates which are calculated using the MITgcm ocean-ice shelf model (Losch, 2008; Holland and Jenkins, 1999; Davis and Nicholls, 2019). The ocean model was initialised and forced with ECCO2 reanalysis (Menemenlis et al., 2005) for 2006-2016 and has compared well with observed seasonal warm water inflow into the cavity and high summer melt rates in the frontal RIS in 2011-2014 (Malyarenko et al., 2019; Stewart et al., 2019). The ice sheet model is run forward for 4 years to allow the grounding line position and ice geometry to relax. These results define the initial state of our control run and sensitivity experiments (Figure 1).

A 20 year forward simulation forced by Surface Mass Balance (SMB) from RACMO2.3 1979-2014 mean (Lenaerts et al., 2012) and by ice shelf basal melt rates from MITgcm 2006-2016 weekly outputs are used in the Automatic Differentiation (AD) package within ISSM. The AD tool maps the sensitivity of ice Volume Above Flotation (VAF) after a 20-year simulation to changes in the chosen parameter (i.e. ice rigidity, basal friction, SMB and basal melt) on the RIS domain. We follow a similar approach as the one described in Morlighem et al. (2021). Specifically, we investigate the sensitivity of the model with respect to the ice rigidity parameter, $B$, which controls the overall ice viscosity defined as:

$90 \mu=\frac{B}{2 \dot{\varepsilon}^{\frac{n-1}{n}}}$

where $\mu$ is the ice viscosity, $\dot{\varepsilon}_{e}$ is the effective strain rate, and $n=3$ is Glen's exponent. We also consider the sensitivity of the model's volume above flotation to the basal friction coefficient parameter, $C_{b}$, defined as:

$\tau_{b}=C_{b}^{2} N v_{b}$

where $\tau_{b}$ is the basal stress, $N$ is the effective pressure (assuming perfect hydrological connectivity to the ocean), and $v_{b}$ is the sliding velocity. Depth-integrated mass continuity arises from:

$\frac{\partial H}{\partial t}=\nabla \cdot H \overline{\mathbf{v}}+\dot{M}_{s}-\dot{M}_{b}$

where $H$ is the ice thickness, $\overline{\mathbf{v}}$ is the depth integrated ice velocity, $\dot{M}_{s}$ is the surface mass balance and $\dot{M}_{b}$ is the ocean-induced melt under floating ice. 
https://doi.org/10.5194/tc-2022-50

Preprint. Discussion started: 3 March 2022

(c) Author(s) 2022. CC BY 4.0 License.

(c) (i)

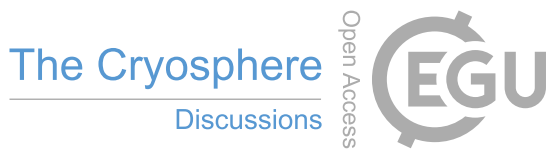

Automatic differentiation provides the gradient of the final VAF, $V$, to a model parameter $P: \mathcal{D} V(P)$. In other words, the first order response of the VAF to a given perturbation $\epsilon \delta P$ in $P$ (where $\epsilon \in \mathbb{R}$, and $\delta P$ is a field defined over the entire model domain $\Omega$ that can be spatially variable) is given by:

$V(P+\epsilon \delta P)=V(P)+\epsilon \int_{\Omega} \mathcal{D} V(P) \delta P d \Omega+\mathcal{O}\left(\epsilon^{2}\right)$.

The gradient, $\mathcal{D} V(P)$, therefore highlights the regions where the model is most sensitive to changes in $P$, and the regions where changes in $P$ would not affect the final VAF at a first order.
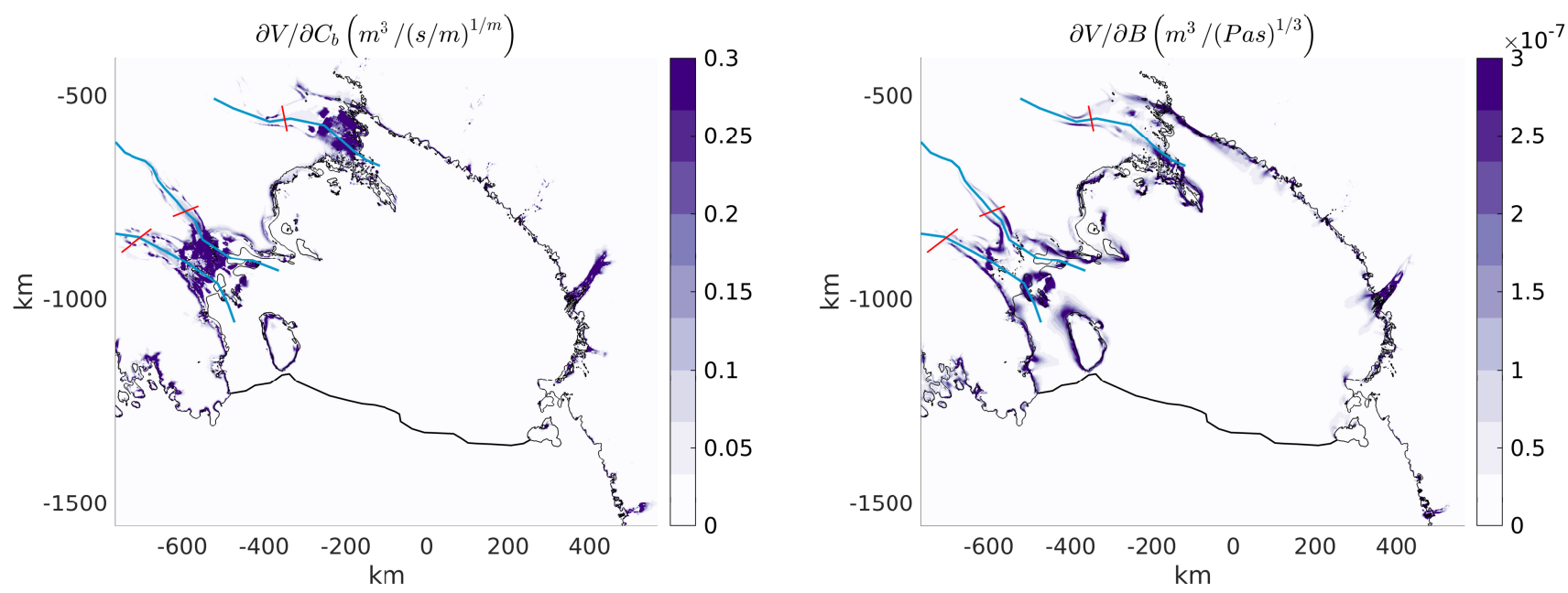

Figure 2. Sensitivity maps of final volume above flotation to the basal friction coefficient $C_{b}$ (left) and ice rigidity $B$ (right) over 20 years. The blue lines highlight the tracks for the along-flow profiles and the red lines the across-flow profiles.

Figure 2 shows the sensitivity maps of the model with respect to the basal friction coefficient, and the ice rigidity parameter. These sensitivity maps show that the vast majority of the grounded ice is not sensitive to changes in friction or rheology, which means that changing the basal friction or ice rigidity over the majority of the region would not significantly influence the overall mass balance over 20 years. Conversely, sensitive areas include the grounding zones, with the active Siple Coast Ice Streams (Mercer, Whillans, Bindschadler and MacAyeal) and Byrd Glacier being the most noticeable grounding zones in the domain. There is high sensitivity to basal friction and ice rigidity along and inboard (i.e. inside of the shear margins) of the ice streams' margins which continues for more than $200 \mathrm{~km}$ upstream of the grounding zones. Figure 3 shows that the sensitivity to basal friction and ice rigidity increase at the major Siple Coast Ice Streams' grounding zones with the sensitivity to ice rigidity continuing to increase downstream of these grounding zones. Figure 4 shows that basal friction and ice rigidity sensitivities are highest at the Whillans and MacAyeal Ice Stream margins. Additionally, Figure 4 shows that basal friction sensitivities 
are highest within Bindschadler Ice Stream trunk and ice rigidity sensitivities are highest at its margins. These sensitivities are positive, highlighting that an increase in basal friction or ice rigidity in these areas would cause an increase in the overall VAF, and also that a decrease in basal friction or ice rigidity would induce a decrease in VAF. Kamb Ice Stream on the Siple Coast
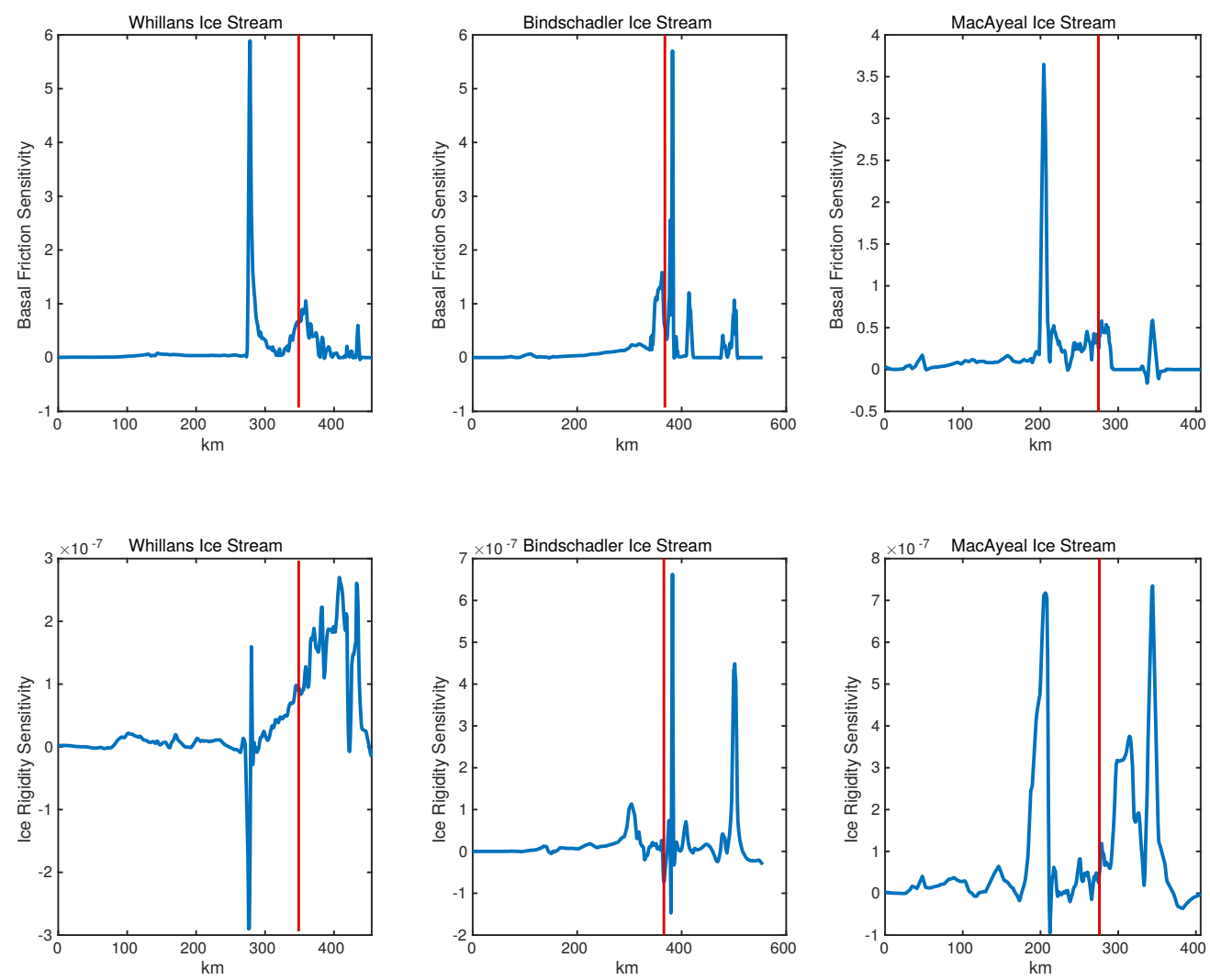

Figure 3. Along-flow profiles of the major active Siple Coast Ice Streams' sensitivity to glaciological controls: basal friction and ice rigidity. $\mathrm{X}$ axis (distance) increases in the downflow direction. The vertical red line highlights the position of the grounding line.

shows low to no sensitivity to changes in the basal friction or ice rigidity highlighting that the Kamb Ice Stream is currently stagnant and thus changing the friction or ice rigidity will not change the ice discharge significantly. In addition, we see that the pinning points of the RIS such as Roosevelt Island and Ross Island are sensitive to changes in basal friction and ice rigidity. In particular, we see that the smaller ice rises (i.e. Crary Ice Rise and Steershead Ice Rise) downstream of the Siple Coast Ice Streams show high sensitivity to changes in ice rigidity. Finally, the interior of the ice sheet, where the ice is slower, shows lower sensitivities due to the time interval used in the model simulation (Morlighem et al., 2021). The sensitivity maps show changes in basal friction and ice rigidity over 20 years therefore it will take some time before changes in velocities upstream impact ice discharge, ice thickness and thus mass balance of the RIS. 

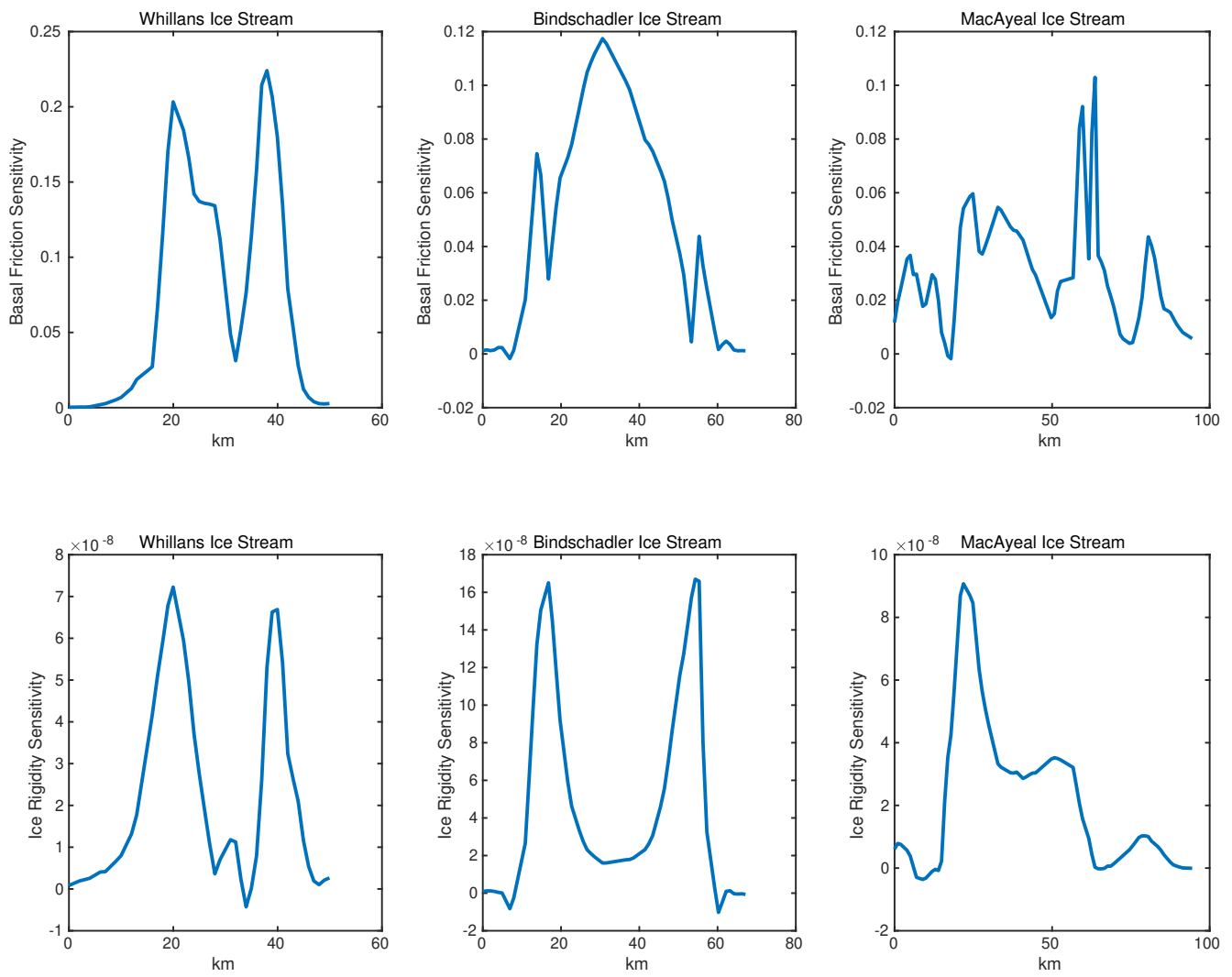

Figure 4. Across-flow profiles of the major active Siple Coast Ice Streams'sensitivity to glaciological controls: basal friction and ice rigidity. These across-flow profiles display sensitivities across the ice streams including their margins.

Figure 5 shows the sensitivity maps of the model with respect to changes in external forcings: surface mass balance, $\dot{M}_{s}$, and basal melting, $\dot{M}_{b}$. The sensitivity map related to SMB shows that most of the grounded ice has a clear positive sensitivity that gradually decreases to 0 as the floating ice is reached. This is expected since floating ice does not contribute directly to VAF, whereas increasing surface mass balance over the grounded ice would lead to a direct increase in VAF. Figure 6 shows this clearly with the major Siple Coast Ice Streams' sensitivity to SMB decreasing to 0 once the floating ice is reached. The highest sensitivities are observed at the grounding zones of the Siple Coast Ice Streams. Figure 5 shows that the transition zone between high and low sensitivity is larger for the faster flowing ice streams and glaciers such as the Siple Coast Ice Streams and Byrd glacier. We can also see that Roosevelt Island and Ross Island pinning points are sensitive to changes in SMB as well as the smaller ice rises downstream of the Siple Coast Ice Streams (i.e. Crary Ice Rise and Steershead Ice Rise). Finally, the sensitivity map related to basal melting shows zero sensitivity over grounded ice, as expected because the model only allows basal melting to be applied on elements that are fully floating, but there is a highly spatially variable pattern on the floating ice. Figure 5 shows a consistently high sensitivity at all grounding zones of the RIS and along the western and eastern ice-shelf shear zones. In particular, we observe a strong sensitivity at the Siple Coast Ice Streams' and Byrd Glacier's grounding zones, 

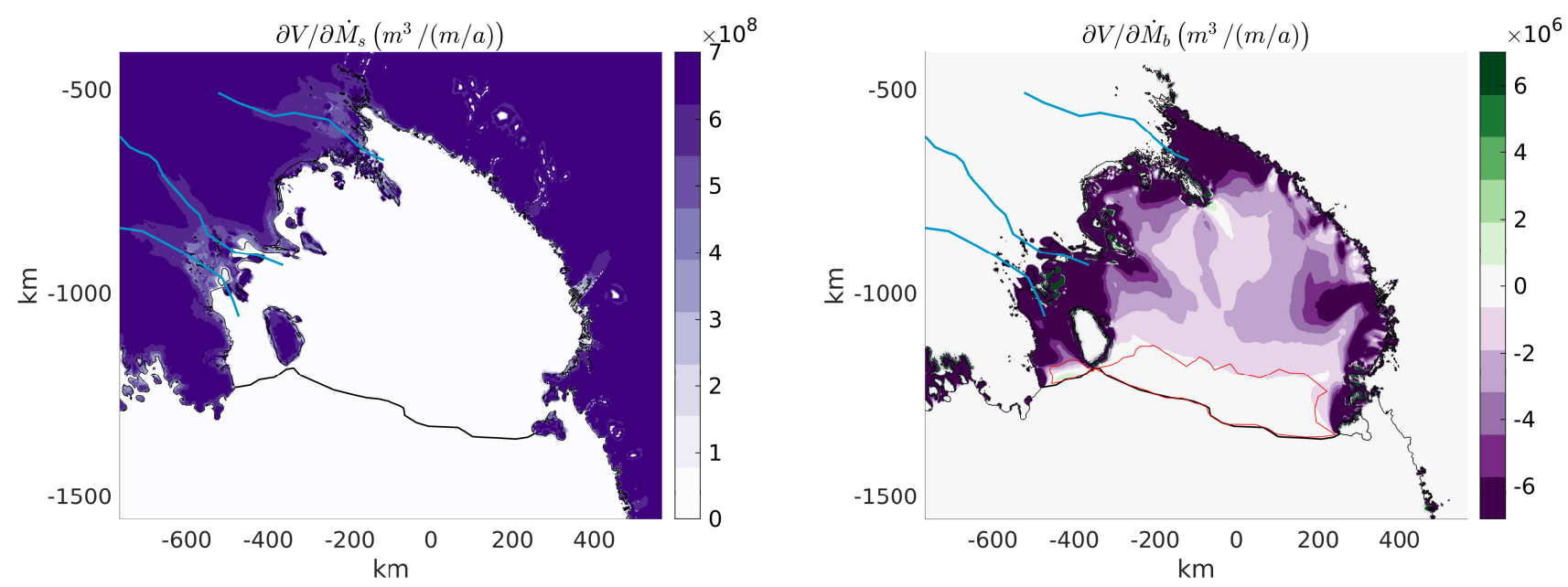

Figure 5. Sensitivity maps of final volume above flotation to the surface mass balance $\dot{M}_{s}$ (left) and basal melting $\dot{M}_{b}$ (right) over 20 years. The 'passive' ice on the RIS identified by Fürst et al. (2016) is outlined in red. The blue lines highlight the tracks for the along-flow profiles.

and the Ross Island shear zone. Additionally, areas of the ice shelf directly downstream from these active ice streams and outlet glaciers are highlighted as sensitive to basal melting changes. The Kamb Ice Stream has high sensitivity directly at the grounding line and near Crary Ice Rise and Siple Dome, while the Bindschadler and MacAyeal Ice Streams have a broad range of sensitivity downstream all the way to Roosevelt Island. All these sensitivities are negative, meaning that an increase in basal melt in these regions would lead to a decrease in the final VAF. Figure 6 confirms that the sensitivity to changes in basal melting is highest at the grounding zones of the major Siple Coast Ice Streams and then reaches negligible sensitivity on the floating ice shelf. In particular, Figure 6 shows that Bindschadler Ice Stream experiences the highest sensitivities at the grounding zone compared to Whillans and MacAyeal Ice Streams. In addition, Figure 5 shows high sensitivities at the pinning points across the RIS: Roosevelt Island, Crary Ice Rise, Steershead Ice Rise and the Shirase Coast Ice Rumples. Finally, no sensitivity to changes in basal melting are observed near the calving front of the RIS (i.e. red outline in 5 showing the 'passive' ice region).

\section{Discussion}

Firstly, the model shows that the grounding zones of the active Siple Coast Ice Streams are particularly sensitive to changes in basal friction and ice rigidity. Previous studies have shown that the Siple Coast Ice Streams are underlain by deformable till that is water-saturated (Kamb, 1991; MacAyeal, 1992; Joughin et al., 2004). Therefore, basal friction at the beds and along the lateral margins are the primary forces resisting flow in these ice streams (Ranganathan et al., 2021). Spatially varying basal friction has been observed at the grounding zones of Bindschadler and MacAyeal Ice Streams with localised areas of relative high drag or subglacial 'sticky spots' providing large resistances to ice flow (MacAyeal, 1992; Joughin et al., 2004; Ranganathan et al., 2021). Our results show that the Bindschadler and MacAyeal Ice Streams have high sensitivities to changes in basal friction at their grounding zones due to these 'sticky spots' being key in controlling the ice discharge. Additionally, 

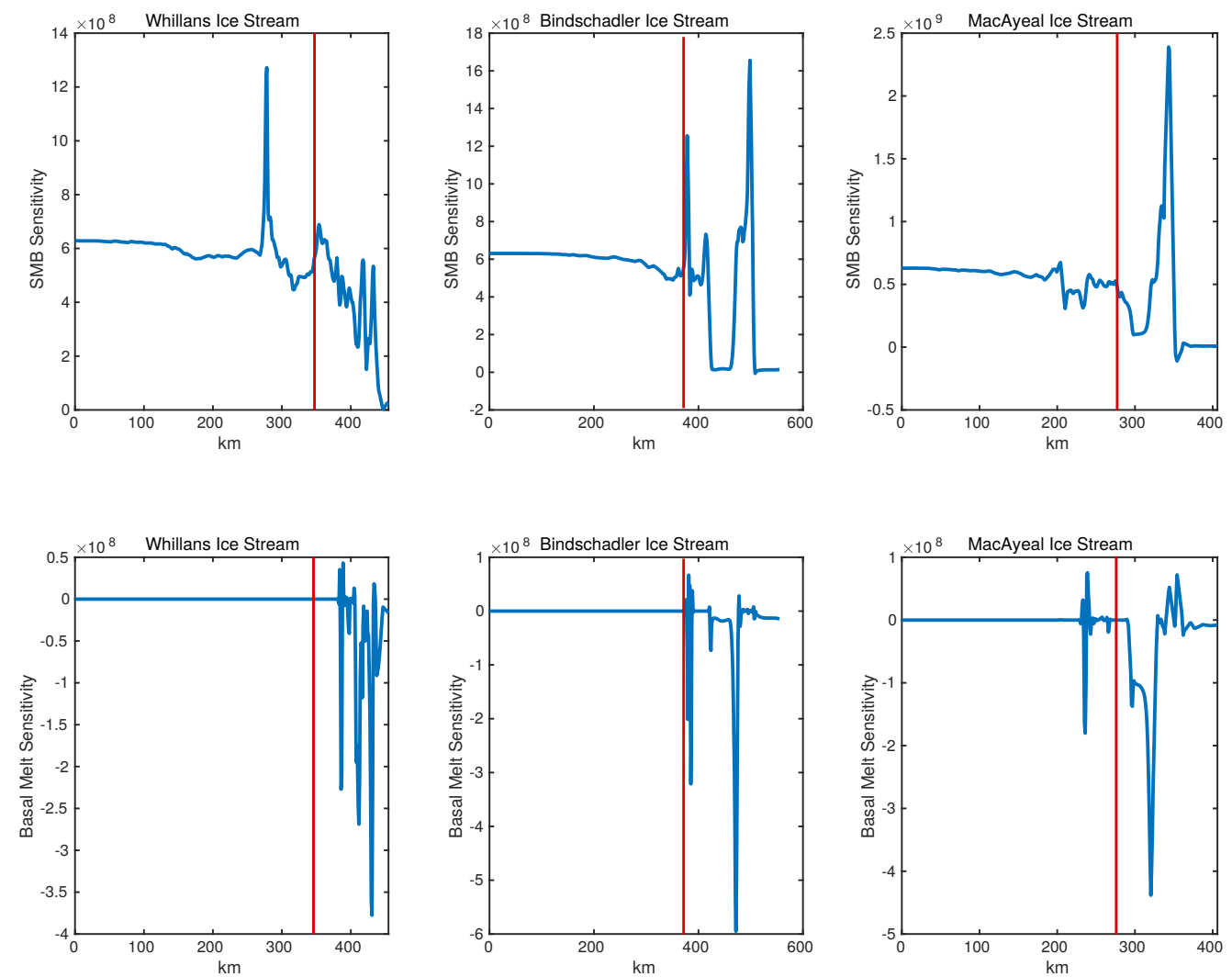

Figure 6. Along-flow profiles of the major active Siple Coast Ice Streams' sensitivity to environmental controls: SMB and basal melting. X axis (distance) increases in the down-flow direction. The vertical red line highlights the position of the grounding line.

our results show that the Whillans Ice Stream has high sensitivities to basal friction changes at its grounding line. Horgan et al. (2021) found relatively stiff till at the grounding line of Whillans Ice Stream compared to the main ice trunk. This stiffer till at the grounding line thickens the ice and stabilizes the position of the grounding line (Joughin et al., 2005; Anandakrishnan et al., 2007; Horgan et al., 2021). A softening of the till at the grounding line through basal friction changes would change the position of the grounding line and discharge rates. This agrees with our results that the grounding zones of Whillans, Bindschadler and MacAyeal Ice Streams display high sensitivities to changes in basal friction as their ice discharge rates are largely controlled by the till conditions at the bed. In addition, our results show that the Siple Coast Ice Streams are highly sensitive to changes in ice rigidity at their grounding zones. It has been shown that changes in temperatures at the grounding zones can promote the ice to soften and deform more easily causing changes in ice discharge and grounding line position (Meyer and Minchew, 2018). Therefore, changes in ice rigidity at the grounding zones of the Siple Coast Ice Streams changes ice flow and discharge rates which impacts the overall mass balance of the RIS domain as shown by our results. 
https://doi.org/10.5194/tc-2022-50

Preprint. Discussion started: 3 March 2022

(c) Author(s) 2022. CC BY 4.0 License.

\section{(c) $\underset{\mathrm{BY}}{\mathrm{BV}}$}

We also see in our results that the Siple Coast Ice Streams' shear margins are highly sensitive to changes in basal friction and ice rigidity. Previous studies have found that temperate ice has formed in the Siple Coast Ice Stream shear margins due to internal heating resulting from changes in crystalline structures (Schoof, 2004; Ranganathan et al., 2021). Minchew et al. (2018) found that the development of crystalline fabric is an important control on ice rigidity in the shear margins, with ice becoming progressively softer downstream due to shear heating. Ice stream widening has been related to this formation of temperate ice and thus a reduction in ice rigidity (Schoof and Hewitt, 2013; Hunter et al., 2021). Our results show that Bindschadler Ice Stream has the highest sensitivity to changes in ice rigidity at the margins, while MacAyeal Ice Stream has a higher sensitivity in the main ice trunk. Meyer and Minchew (2018) show that Bindschadler Ice Stream has temperate zones of ice within its shear margins and thus changes in ice rigidity here would influence the ice stream discharge as shown by our results. On the other hand, Winberry et al. (2009) found that the MacAyeal Ice Stream has a stick-slip behaviour, suggesting that the basal rheology within the main ice trunk is more important in controlling the ice discharge, which agrees with our results. In addition, it has been suggested that internal heating interacts with drainage at the bed forming a channelised drainage system (Suckale et al., 2014; Ranganathan et al., 2021). Our results show that the Bindschadler Ice Stream margins are a highly sensitive region to changes in basal friction. Meyer and Minchew (2018) found evidence of a channelised drainage system near the temperate zones of Bindschadler Ice Stream shear margins, which has the potential to change the basal friction and cause changes in the ice stream discharge and flow rates. In addition, Van Der Veen et al. (2007) found lubricated conditions under Whillans Ice Stream due to nearby meltwater production under its shear margins. Our results show that Whillans Ice Stream is highly sensitive to changes in basal friction at its margins suggesting that changes in lubrication conditions here influences the flow and discharge rates of the ice stream. Recently, the Whillans and MacAyeal Ice Streams have been decelerating, while the Bindschadler Ice Stream has been accelerating due to changes at the ice streams' beds and margins (Hulbe and Fahnestock, 2004; Joughin et al., 2005; Horgan et al., 2012; Van Der Wel et al., 2013) highlighting that basal friction and ice rigidity have a large influence over ice stream discharge.

The sensitivity map for SMB changes shows that the longer the ice remains grounded the larger the sensitivity to changes in SMB. Our results show that grounded ice is four times more sensitive than floating ice. Sensitivity to changes in SMB is observed at the grounding zones, with the Whillans Ice Stream grounding zone shown to have the highest sensitivity at its grounding line. Previous studies have shown that Whillans Ice Stream has thicker ice at the grounding line, which stabilizes the grounding line position (Joughin et al., 2005; Anandakrishnan et al., 2007). Therefore, our results show high sensitivity at the Whillans Ice Stream grounding line due to changes in SMB driving changes in the ice thickness, grounding line stability and ice stream discharge. In addition, high sensitivity to changes in SMB is found at the Ross Island and Roosevelt Island pinning points on the floating ice shelf. Pinning points are localised areas of grounding within a floating ice shelf and thus any changes in the SMB here would promote ice thickness and discharge changes on the RIS (Reese et al., 2018; Gudmundsson et al., 2019; Still et al., 2019).

Furthermore, our results show that the grounding zones of the Siple Coast Ice Streams are highly sensitive to changes in basal melting. The grounding lines show high negative sensitivities because changes in basal melting in these regions lead to changes in grounding line position, ice discharge and thus mass loss (Moholdt et al., 2014; Pattyn et al., 2017; Shepherd et al., 
https://doi.org/10.5194/tc-2022-50

Preprint. Discussion started: 3 March 2022

(c) Author(s) 2022. CC BY 4.0 License.

2018; Gudmundsson et al., 2019). Basal melting can influence changes in basal friction and ice rigidity causing the Siple Coast Ice Streams' dynamics to change. For example, ocean heat content will dictate the temperature of the ice at the grounding line and rate of basal melting, changing basal friction and ice rigidity. Currently, the RIS has consistent low basal melt rates near the grounding lines due to the shallower and more uniform ice draft as well as weaker tidal currents (Moholdt et al., 2014). However, Marsh et al. (2016) found changes in basal melt rates of 15-22 $\mathrm{m} \mathrm{a}^{-1}$ near the grounding line of the Whillans Ice Stream due to high subglacial discharge forming a well-defined basal channel. In addition, Adusumilli et al. (2020) found varying basal melt rates of $0-1.5 \mathrm{~m} \mathrm{a}^{-1}$ at the grounding zones of the active Siple Coast Ice Streams. This highlights that changes in basal melting is currently occurring in the areas identified as sensitive and would have greatest impact on the final VAF.

Additionally, our results show that changes in basal friction and ice rigidity at Byrd Glacier would lead to large changes in the rate of mass loss. Byrd glacier is the largest outlet glacier draining through the Transantarctic Mountains and it has been shown that Byrd Glacier experiences variability on a range of timescales as a response to changes in its subglacial hydrogical conditions (Stearns et al., 2008). This concurs with our results showing that Byrd Glacier is highly sensitive to changes in basal friction within its main ice trunk and shear margins. In addition, it has been shown that fast deformation persist in the Byrd Glacier shear margins (Ledoux et al., 2017) and this makes it highly sensitive to changes in ice rigidity as shown by our results. Our results also show high negative sensitivities to changes in basal melting at the grounding zone of Byrd Glacier. These high negative sensitivities are due to Byrd Glacier having a reverse bedrock slope, which drives changes in grounding line position and ice discharge in response to changes in basal melting (Schoof, 2007; Stearns et al., 2008; Van Der Veen et al., 2014; Pattyn et al., 2017). Adusumilli et al. (2020) found basal melt rates ranging 4-6 $\mathrm{m} \mathrm{a}^{-1}$ at the grounding zone of Byrd Glacier indicating that this region is important to monitor in relation to the future mass balance of the RIS. We see that the active Siple Coast Ice Streams and Byrd Glacier have similar sensitivities to changes in basal friction, ice rigidity and basal melting. However, changes at the Siple Coast Ice Streams result in far greater ice loss as they discharge large volumes of ice directly from WAIS into the RIS, they have deformable till at their beds and their shear margins can migrate (Shabtaie and Bentley, 1987; Bennett, 2003; Bindschadler et al., 2003; Catania et al., 2012; Muto et al., 2013). However, the numerical model is only able to capture the lower bound sensitivity estimates of the Siple Coast Ice Streams as the model does not include these processes which would favour greater ice discharge and mass loss.

High sensitivity to changes in basal friction, ice rigidity and basal melting is also found near pinning points (i.e. Ross Island, Roosevelt Island, Steershead and Crary ice rises and Shirase Coast Ice Rumples) on the RIS. These regions are important for the stability of the RIS because they provide resistance to the ice flow from grounded ice and help buttress the ice shelf (Dupond and Alley, 2005; Fürst et al., 2016; Reese et al., 2018; Still et al., 2019). Thus, a change in the basal friction and ice rigidity in these regions would change the resistive effect of pinning points on the RIS (Meyer and Minchew, 2018; Alley et al., 2019; Still et al., 2019) and overall mass balance as shown by our results. In addition, changes in basal melting can result in detachment from pinning points and grounding line retreat (Still et al., 2019). Once the ice shelf has become detached from these pinning points, the balance of forces across the RIS will change inducing changes in ice flow, thickness and thus mass balance (Still et al., 2019; Reese et al., 2018). Gudmundsson et al. (2019) indicated that rapid melting identified near Ross Island influences 
https://doi.org/10.5194/tc-2022-50

Preprint. Discussion started: 3 March 2022

(c) Author(s) 2022. CC BY 4.0 License.

(c) (i)

a structurally critical region in which ice thickness changes can influence the flow speed of the entire RIS. Additionally, Reese et al. (2018) highlighted that the Bindschadler Ice Stream flow was influenced in response to thinning at the Ross Island region (more than $900 \mathrm{~km}$ away). Our results concur with these studies in that Ross Island is an important region to monitor due to it being identified as a region of high buttressing potential (Fürst et al., 2016) and its high sensitivity to changes in basal melting having a large impact on the final mass balance of the RIS.

Finally, the calving front of the RIS shows no sensitivities to changes in basal melting impacting the final VAF. This is consistent with Fürst et al. (2016), who identified this region as "passive”. However, removal of this 'passive region' could result in the current summer production of the warm ASW (Stewart et al., 2019) reaching sensitive areas of the RIS (Fürst et al., 2016). Tinto et al. (2019) show that the role of climate variations in destabilizing the RIS may have depended on the position of the ice shelf front in the past. For example, during the last glacial maximum, the ice sheet grounding line was near the edge of the continental shelf and thus relatively warmed CDW would have been able to flow into the sub-ice cavity, generating high melt rates at the grounding lines of the RIS (Tinto et al., 2019). We see that there is higher negative sensitivities to changes in basal melting at the grounding lines compared to the ice shelf shear zones and pinning points of the RIS. However, there needs to be change in the position of the ice shelf front, ocean circulation/mixing and strength of tidal currents to encourage changes in basal melt rates at the grounding lines of the RIS (Moholdt et al., 2014).

\section{Conclusions}

In this study, we demonstrate the capability of AD to provide fine scale sensitivity maps of the RIS domain. These sensitivity maps indicate where changes in the environmental and glaciological controls would have the greatest impact on the mass balance of the RIS domain. Overall, we find that the final VAF for the modelled domain is highly sensitive to changes in basal friction and ice rigidity at the grounding zones and shear margins of the active Siple Coast Ice Streams and Byrd glacier. The sensitivity to changes in these glaciological controls at the RIS pinning points is smaller compared to the grounding zones. However, these pinning point regions have potentially larger dynamical impacts across the RIS. Finally, the final VAF for the modelled domain is highly sensitive to changes in SMB over the grounded portion of the RIS, while highly sensitive to changes in basal melting at the grounding zones, pinning points and ice shelf-shear margins of the RIS. The highest sensitivity to changes in both glaciological and environmental controls is observed at the grounding zones of the Siple Coast Ice Streams and Transantarctic Mountains Outlet Glaciers. These results show that the RIS mass balance is highly sensitive to changes in ocean circulation and mixing as well as tidal currents which could potentially drive changes in basal melt rates at the calving front at the grounding zones. Therefore, more work is needed to understand the complex ice-ocean interactions at the groundings zones as this study identifies that these regions are important for the mass balance of the RIS. Thus, these sensitivity maps should be used to inform future field campaigns on which areas of the RIS are sensitive and should be monitored. 
https://doi.org/10.5194/tc-2022-50

Preprint. Discussion started: 3 March 2022

(c) Author(s) 2022. CC BY 4.0 License.

(c) (i)

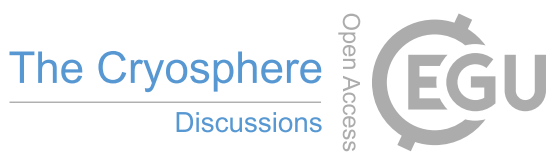

270 Data availability. The Ice-sheet and Sea-level System Model can be accessed at https://issm.jpl.nasa.gov (we used version 4.18). BedMachine Antarctica is available at NSIDC (http://nsidc.org/data/nsidc-0756). InSAR-Based ice velocity is found at NSIDC (https://nsidc.org/data/nsidc0484/). The Antarctic surface mass balance (RACMO 2.3) is available at https://www.projects.science.uu.nl/iceclimate/models/antarctica.php.

Author contributions. ISSM simulations and AD analysis were carried out by Francesca Baldacchino under the guidance of Mathieu Morlighem. AD simulations were carried out by Mathieu Morlighem. Manuscript was written by Francesca Baldacchino with contribu275 tions from Mathieu Morlighem, Nicholas Golledge, Huw Horgan and Alena Malyarenko. MITgcm basal melt outputs were provided by Alena Malyarenko.

Competing interests. The authors declare that they have no conflict of interest.

Acknowledgements. This work was supported by the New Zealand Ministry for Business, Innovation and Employment contracts RTUV1705 (“NZSeaRise”) and ANTA1801 (“Antarctic Science Platform”), and Royal Society of New Zealand contract VUW-1501. 
https://doi.org/10.5194/tc-2022-50

Preprint. Discussion started: 3 March 2022

(c) Author(s) 2022. CC BY 4.0 License.

(c) (i)

\section{References}

Adusumilli, S., Fricker, H. A., Medley, B., Padman, L., and Siegfried, M. R.: Interannual variations in meltwater input to the Southern Ocean from Antarctic ice shelves, Nature Geoscience, 13, 616-620, https://doi.org/10.1038/s41561-020-0616-z, 2020.

Alley, K. E., Scambos, T. A., Alley, R. B., and Holschuh, N.: Troughs developed in ice-stream shear margins precondition ice shelves for ocean-driven breakup, Science Advances, 5, https://doi.org/10.1126/sciadv.aax2215, 2019.

Anandakrishnan, S., Catania, G. A., Alley, R. B., and Horgan, H. J.: Discovery of till deposition at the grounding line of Whillans Ice Stream, Science, 315, 1835-1838, https://doi.org/10.1126/science.1138393, 2007.

Assmann, K., Hellmer, H. H., and Beckmann, A.: Seasonal variation in circulation and water mass distribution on the Ross Sea continental shelf, Antarctic Science, 15, 3-11, https://doi.org/10.1017/S0954102003001007, 2003.

Bennett, M. R.: Ice streams as the arteries of an ice sheet: Their mechanics, stability and significance, Earth-Science Reviews, 61, 309-339, https://doi.org/10.1016/S0012-8252(02)00130-7, 2003.

Bindschadler, R. A., Vornberger, P. L., King, M. A., and Padman, L.: Tidally driven stick-slip motion in the mouth of Whillans Ice Stream, Antarctica, Annals of Glaciology, 36, 263-272, https://doi.org/10.3189/172756403781816284, 2003.

Budd, W. F., Keage, P. L., and Blundy, N. A.: Empirical studies of ice sliding, J. Glaciol., 23, 157-170, 1979.

Catania, G., Hulbe, C., Conway, H., Scambos, T. A., and Raymond, C. F.: Variability in the mass flux of the Ross ice streams, West Antarctica, over the last millennium, Journal of Glaciology, 58, 741-752, https://doi.org/10.3189/2012JoG11J219, 2012.

Das, I., Padman, L., Bell, R. E., Fricker, H. A., Tinto, K. J., Hulbe, C. L., Siddoway, C. S., Dhakal, T., Frearson, N. P., Mosbeux, C., Cordero, S. I., and Siegfried, M. R.: Multidecadal Basal Melt Rates and Structure of the Ross Ice Shelf, Antarctica, Using Airborne Ice Penetrating Radar, Journal of Geophysical Research: Earth Surface, 125, https://doi.org/10.1029/2019JF005241, 2020.

Davis, P. and Nicholls, K.: Turbulence observations beneath larsen C ice shelf, Antarctica., J. Geophys. Res, 124, 5529-5550, https://doi.org/10.1029/2019jc015164, 2019.

Dinniman, M. S., Klinck, J. M., and Smith, W. O.: A model study of Circumpolar Deep Water on the West Antarctic Peninsula and Ross Sea continental shelves, Deep-Sea Research Part II: Topical Studies in Oceanography, 58, 1508-1523, https://doi.org/10.1016/j.dsr2.2010.11.013, 2011.

Dirscherl, M., Dietz, A. J., Dech, S., and Kuenzer, C.: Remote sensing of ice motion in Antarctica - A review, Remote Sensing of Environment, 237, 111 595, https://doi.org/10.1016/j.rse.2019.111595, 2020.

Dupond, T. and Alley, R.: Assessment of the importance of ice-shelf buttressing to ice-sheet flow., Journal of Geophysical Research Letters, $32,2005$.

Fürst, J. J., Durand, G., Gillet-Chaulet, F., Tavard, L., Rankl, M., Braun, M., and Gagliardini, O.: The safety band of Antarctic ice shelves, Nature Climate Change, 6, 479-482, https://doi.org/10.1038/nclimate2912, 2016.

Gagliardini, O., Durand, G., Zwinger, T., Hindmarsh, R. C., and Le Meur, E.: Coupling of ice-shelf melting and buttressing is a key process in ice-sheets dynamics, Geophysical Research Letters, 37, 1-5, https://doi.org/10.1029/2010GL043334, 2010.

Golledge, N. R., Keller, E. D., Gomez, N., Naughten, K. A., Bernales, J., Trusel, L. D., and Edwards, T. L.: Global environmental consequences of twenty-first-century ice-sheet melt, Nature, 566, 65-72, https://doi.org/10.1038/s41586-019-0889-9, 2019.

Gudmundsson, G. H.: Ice-shelf buttressing and the stability of marine ice sheets, Cryosphere, 7, 647-655, https://doi.org/10.5194/tc-7-647$2013,2013$. 
https://doi.org/10.5194/tc-2022-50

Preprint. Discussion started: 3 March 2022

(c) Author(s) 2022. CC BY 4.0 License.

(c) (i)

Gudmundsson, G. H., Paolo, F. S., Adusumilli, S., and Fricker, H. A.: Instantaneous Antarctic ice sheet mass loss driven by thinning ice shelves, Geophysical Research Letters, 46, 13 903-13 909, https://doi.org/10.1029/2019GL085027, 2019.

Holland, D. and Jenkins, A.: Modeling Thermodynamic Ice-Ocean Interactions at the Base of an Ice Shelf., Journal of Physical Oceanography, 29, 1787-1800, https://doi.org/10.1175/1520-0485, 1999.

Horgan, H. J., Walker, R. T., Anandakrishnan, S., and Alley, R. B.: Surface elevation changes at the front of the Ross Ice Shelf: Implications for basal melting, Journal of Geophysical Research: Oceans, 116, 1-12, https://doi.org/10.1029/2010JC006192, 2011.

Horgan, H. J., Anandakrishnan, S., Jacobel, R. W., Christianson, K., Alley, R. B., Heeszel, D. S., Picotti, S., and Walter, J. I.: Subglacial Lake Whillans - Seismic observations of a shallow active reservoir beneath a West Antarctic ice stream, Earth and Planetary Science Letters, 331-332, 201-209, https://doi.org/10.1016/j.epsl.2012.02.023, 2012.

Horgan, H. J., van Haastrecht, L., Alley, R. B., Anandakrishnan, S., Beem, L. H., Christianson, K., Muto, A., and Siegfried, M. R.: Grounding zone subglacial properties from calibrated active-source seismic methods, The Cryosphere, 15, 1863-1880, https://doi.org/10.5194/tc-151863-2021, 2021.

Hulbe, C. L. and Fahnestock, M. A.: West Antarctic ice-stream discharge variability: mechanism, controls and pattern of grounding-line retreat, Journal of Glaciology, 50, 471-484, https://doi.org/10.3189/172756504781829738, 2004.

Hunter, P., Meyer, C., Minchew, B., Haseloff, M., and Rempel, A.: Thermal controls on ice stream shear margins, Journal of Glaciology, 67, 435-449, https://doi.org/10.1017/jog.2020.118, 2021.

Jenkins, A., Shoosmith, D., Dutrieux, P., Jacobs, S., Kim, T. W., Lee, S. H., Ha, H. K., and Stammerjohn, S.: West Antarctic Ice Sheet retreat in the Amundsen Sea driven by decadal oceanic variability, Nature Geoscience, 11, 733-738, https://doi.org/10.1038/s41561-018-0207-4, 2018.

Joughin, I., MacAyeal, D. R., and Tulaczyk, S.: Basal shear stress of the Ross ice streams from control method inversions, Journal of Geophysical Research: Solid Earth, 109, 1-20, https://doi.org/10.1029/2003JB002960, 2004.

Joughin, I., Bindschadler, R. A., King, M. A., Voigt, D., Alley, R. B., Anandakrishnan, S., Horgan, H., Peters, L., Winberry, P., Das, S. B., and Catania, G.: Continued deceleration of Whillans ice stream West Antartica, Geophysical Research Letters, 32, 1-4, https://doi.org/10.1029/2005GL024319, 2005.

Kamb, B.: Rheological Nonlinearity and Flow Instability in the Deforming Bed Mechanism of Ice Stream Motion, Journal of Geophysical Research, https://doi/epdf/10.1029/91JB00946, 1991.

Kenneally, J. P. and Hughes, T. J.: Basal melting along the floating part of Byrd Glacier, Antarctic Science, 16, 355-358, https://doi.org/10.1017/S0954102004002068, 2004.

Klein, E., Mosbeux, C., Bromirski, P. D., Padman, L., Bock, Y., Springer, S. R., and Fricker, H. A.: Annual cycle in flow of Ross Ice Shelf, Antarctica: Contribution of variable basal melting, Journal of Glaciology, 66, 861-875, https://doi.org/10.1017/jog.2020.61, 2020.

Ledoux, C. M., Hulbe, C. L., Forbes, M. P., Scambos, T. A., and Alley, K.: Structural provinces of the Ross Ice Shelf, Antarctica, Annals of Glaciology, 58, 88-98, https://doi.org/10.1017/aog.2017.24, 2017.

Lenaerts, J. T., Van Den Broeke, M. R., Van De Berg, W. J., Van Meijgaard, E., and Kuipers Munneke, P.: A new, high-resolution surface mass balance map of Antarctica (1979-2010) based on regional atmospheric climate modeling, Geophysical Research Letters, 39, 1-5, https://doi.org/10.1029/2011GL050713, 2012.

Losch, M.: Modeling ice shelf cavities in a z coordinate ocean general circulation model, Journal of Geophysical Research: Oceans (1978-2012), 113, https://doi.org/10.1029/2007jc004368, 2008. 
https://doi.org/10.5194/tc-2022-50

Preprint. Discussion started: 3 March 2022

(c) Author(s) 2022. CC BY 4.0 License.

(c) (i)

M. Sagebaum, T. Albring, N. G.: High-Performance Derivative Computations using CoDiPack, ACM Transactions on Mathematical Software (TOMS), 45, https://dl.acm.org/doi/abs/10.1145/3356900, 2019.

MacAyeal, D. R.: Large scale ice flow over viscous basal sediment, Journal of Geophysical Research Solid Earth, 94, 4071-4087, https://doi.org/http://dx.doi.org/10.1029/JB094iB04p04071, doi:10.1029/JB094iB04p04071, 1989.

MacAyeal, D. R.: Irregular oscillations of the West Antarctic ice sheet, Nature, https://doi.org/10.1038/359029a0, 1992.

Malyarenko, A., Robinson, N. J., Williams, M. J. M., and Langhorne, P. J.: A Wedge Mechanism for Summer Surface Water Inflow Into the Ross Ice Shelf Cavity, Journal of Geophysical Research: Oceans, 124, 1196-1214, https://doi.org/10.1029/2018jc014594, 2019.

Marsh, O. J., Fricker, H. A., Siegfried, M. R., Christianson, K., Nicholls, K. W., Corr, H. F., and Catania, G.: High basal melting forming a channel at the grounding line of Ross Ice Shelf, Antarctica, Geophysical Research Letters, 43, 250-255, https://doi.org/10.1002/2015GL066612, 2016.

Menemenlis, D., Hill, C., Adcrocft, A., Campin, J.-M., Cheng, B., Ciotti, B., Fukumori, I., Heimbach, P., Henze, C., Köhl, A., Lee, T., Stammer, D., Taft, J., and Zhang, J.: NASA supercomputer improves prospects for ocean climate research, Eos, Transactions American Geophysical Union, 86, 89-96, https://doi.org/https://doi.org/10.1029/2005EO090002, 2005.

Meyer, C. R. and Minchew, B. M.: Temperate ice in the shear margins of the Antarctic Ice Sheet: Controlling processes and preliminary locations, Earth and Planetary Science Letters, 498, 17-26, https://doi.org/10.1016/j.eps1.2018.06.028, 2018.

Minchew, B. M., Meyer, C. R., Robel, A. A., Gudmundsson, G. H., and Simons, M.: Processes controlling the downstream evolution of ice rheology in glacier shear margins: Case study on Rutford Ice Stream, West Antarctica, Journal of Glaciology, 64, 583-594, https://doi.org/10.1017/jog.2018.47, 2018.

Moholdt, G., Padman, L., and Fricker, H. A.: Basal mass budget of Ross and Filchner-Ronne ice shelves, Antarctica, derived from Lagrangian analysis of ICESat altimetry, Journal of Geophysical Research F: Earth Surface, 119, 2361-2380, https://doi.org/10.1002/2014JF003171, 2014.

Morlighem, M.and Rignot, E. and Binder, T.: Deep glacial troughs and stabilizing ridges unveiled beneath the margins of the Antarctic ice sheet., Nat. Geosci., 13, 132-137, https://doi.org/10.1038/s41561-019-0510-8, 2020.

Morlighem, M., Seroussi, H., Larour, E., and Rignot, E.: Inversion of basal friction in Antarctica using exact and incomplete adjoints of a higher-order model, Journal of Geophysical Research: Earth Surface, 118, 1746-1753, https://doi.org/https://doi.org/10.1002/jgrf.20125, 2013.

Morlighem, M., Goldberg, D., Dias dos Santos, T., Lee, J., and Sagebaum, M.: Mapping the Sensitivity of the Amundsen Sea Embayment to Changes in External Forcings Using Automatic Differentiation, Geophysical Research Letters, 48, e2021GL095440, https://doi.org/https://doi.org/10.1029/2021GL095440, e2021GL095440 2021GL095440, 2021.

Mottram, R., Hansen, N., Kittel, C., Van Wessem, M., Agosta, C., Amory, C., Boberg, F., Jan Van De Berg, W., Fettweis, X., Gossart, A., Van Lipzig, N. P. M., Van Meijgaard, E., Orr, A., Phillips, T., Webster, S., Simonsen, S. B., and Souverijns, N.: What is the Surface Mass Balance of Antarctica? An Intercomparison of Regional Climate Model Estimates, The Cyrosphere, (submitted, 1-42, http://www.cordex. org/, 2020.

Muto, A., Christianson, K., Horgan, H. J., Anandakrishnan, S., and Alley, R. B.: Bathymetry and geological structures beneath the Ross Ice Shelf at the mouth of Whillans Ice Stream, West Antarctica, modeled from ground-based gravity measurements, Journal of Geophysical Research: Solid Earth, 118, 4535-4546, https://doi.org/10.1002/jgrb.50315, 2013.

Pattyn, F.: The paradigm shift in Antarctic ice sheet modelling, Nature Communications, 9, 10-12, https://doi.org/10.1038/s41467-018$05003-\mathrm{z}, 2018$. 
https://doi.org/10.5194/tc-2022-50

Preprint. Discussion started: 3 March 2022

(c) Author(s) 2022. CC BY 4.0 License.

(c) (i)

Pattyn, F. and Durand, G.: Why marine ice sheet model predictions may diverge in estimating future sea level rise, Geophysical Research Letters, 40, 4316-4320, https://doi.org/10.1002/grl.50824, 2013.

Pattyn, F., Favier, L., Sun, S., and Durand, G.: Progress in Numerical Modeling of Antarctic Ice-Sheet Dynamics, Current Climate Change Reports, 3, 174-184, https://doi.org/10.1007/s40641-017-0069-7, 2017.

Pritchard, H. D., Ligtenberg, S. R., Fricker, H. A., Vaughan, D. G., Van Den Broeke, M. R., and Padman, L.: Antarctic ice-sheet loss driven by basal melting of ice shelves, Nature, 484, 502-505, https://doi.org/10.1038/nature10968, 2012.

Raftery, A. E., Zimmer, A., Frierson, D. M., Startz, R., and Liu, P.: Less than $2{ }^{\circ} \mathrm{c}$ warming by 2100 unlikely, Nature Climate Change, 7 , 637-641, https://doi.org/10.1038/nclimate3352, 2017.

Ranganathan, M., Minchew, B., Meyer, C. R., and Gudmundsson, G. H.: A new approach to inferring basal drag and ice rheology in ice streams, with applications to West Antarctic Ice Streams, Journal of Glaciology, 67, 229-242, https://doi.org/10.1017/jog.2020.95, 2021.

Reese, R., Gudmundsson, G. H., Levermann, A., and Winkelmann, R.: The far reach of ice-shelf thinning in Antarctica, Nature Climate Change, 8, 53-57, https://doi.org/10.1038/s41558-017-0020-x, 2018.

Rignot, E., Jacobs, S., Mouginot, J., and Scheuchl, B.: Ice-shelf melting around antarctica, Science, 341, 266-270, https://doi.org/10.1126/science.1235798, 2013.

405 Rignot, E., Mouginot, J., Morlighem, M., Seroussi, H., and Scheuchl, B.: Widespread, rapid grounding line retreat of Pine Island, Thwaites, Smith, and Kohler glaciers, West Antarctica, from 1992 to 2011, Geophysical Research Letters, 41, 3502-3509, https://doi.org/https://doi.org/10.1002/2014GL060140, 2014.

Rignot, E., Mouginot, J., , and Scheuchl, B.: MEaSUREs InSAR-Based Antarctica Ice Velocity Map, Version 2., Boulder, Colorado USA. NASA National Snow and Ice Data Center Distributed Active Archive Center., https://doi.org/10.5067/D7GK8F5J8M8R, 2017.

410 Rignot, E., Mouginot, J., Scheuchl, B., van den Broeke, M., van Wessem, M. J., and Morlighem, M.: Four decades of Antarctic Ice Sheet mass balance from 1979-2017, Proceedings of the National Academy of Sciences, 116, 1095-1103, https://doi.org/10.1073/pnas.1812883116, 2019.

Robel, A. A., Seroussi, H., and Roe, G. H.: Marine ice sheet instability amplifies and skews uncertainty in projections of future sea-level rise, Proceedings of the National Academy of Sciences of the United States of America, 116, 14887-14892, https://doi.org/10.1073/pnas.1904822116, 2019.

Schodlok, M., Menemenlis, D., and Rignot, E.: Ice shelf basal melt rates around Antarctica from simulations and observations., Journal of Geophysical Research, 121, 1085-1109, https://doi.org/10.1002/2015JC011117, 2016.

Schoof, C.: On the mechanics of ice-stream shear margins, Journal of Glaciology, 50, 208-218, https://doi.org/10.3189/172756504781830024, 2004.

Schoof, C.: Ice sheet grounding line dynamics: Steady states, stability, and hysteresis, Journal of Geophysical Research: Earth Surface, 112, 1-19, https://doi.org/10.1029/2006JF000664, 2007.

Schoof, C. and Hewitt, I.: Ice-sheet dynamics, Annual Review of Fluid Mechanics, 45, 217-239, https://doi.org/10.1146/annurev-fluid011212-140632, 2013.

Seroussi, H., Morlighem, M., Larour, E., Rignot, E., and Khazendar, A.: Hydrostatic grounding line parameterization in ice sheet models, The Cryosphere, 8, 2075-2087, https://doi.org/10.5194/tc-8-2075-2014, 2014.

Shabtaie, S. and Bentley, C.: West Antarctic ice streams draining into the Ross Ice Shelf: configuration and mass balance., Journal of Geophysical Research, 92, 1311-1336, https://doi.org/10.1029/JB092iB02p01311, 1987. 
https://doi.org/10.5194/tc-2022-50

Preprint. Discussion started: 3 March 2022

(c) Author(s) 2022. CC BY 4.0 License.

(c) (i)

Shepherd, A., Ivins, E. R., Geruo, A., Barletta, V. R., Bentley, M. J., Bettadpur, S., Briggs, K. H., Bromwich, D. H., Forsberg, R., Galin, N., Horwath, M., Jacobs, S., Joughin, I., King, M. A., Lenaerts, J. T., Li, J., Ligtenberg, S. R., Luckman, A., Luthcke, S. B., McMillan, M., Meister, R., Milne, G., Mouginot, J., Muir, A., Nicolas, J. P., Paden, J., Payne, A. J., Pritchard, H., Rignot, E., Rott, H., Sørensen, L. S., Scambos, T. A., Scheuchl, B., Schrama, E. J., Smith, B., Sundal, A. V., Van Angelen, J. H., Van De Berg, W. J., Van Den Broeke, M. R., Vaughan, D. G., Velicogna, I., Wahr, J., Whitehouse, P. L., Wingham, D. J., Yi, D., Young, D., and Zwally, H. J.: A reconciled estimate of ice-sheet mass balance, Science, 338, 1183-1189, https://doi.org/10.1126/science.1228102, 2012.

Shepherd, A., Ivins, E., Rignot, E., Smith, B., Van Den Broeke, M., Velicogna, I., Whitehouse, P., Briggs, K., Joughin, I., Krinner, G.,

Nowicki, S., Payne, T., Scambos, T., Schlegel, N., Geruo, A., Agosta, C., Ahlstrøm, A., Babonis, G., Barletta, V., Blazquez, A., Bonin, J., Csatho, B., Cullather, R., Felikson, D., Fettweis, X., Forsberg, R., Gallee, H., Gardner, A., Gilbert, L., Groh, A., Gunter, B., Hanna, E., Harig, C., Helm, V., Horvath, A., Horwath, M., Khan, S., Kjeldsen, K. K., Konrad, H., Langen, P., Lecavalier, B., Loomis, B., Luthcke, S., McMillan, M., Melini, D., Mernild, S., Mohajerani, Y., Moore, P., Mouginot, J., Moyano, G., Muir, A., Nagler, T., Nield, G., Nilsson, J., Noel, B., Otosaka, I., Pattle, M. E., Peltier, W. R., Pie, N., Rietbroek, R., Rott, H., Sandberg-Sørensen, L., Sasgen, I., Save, H., Scheuchl, B., Schrama, E., Schröder, L., Seo, K. W., Simonsen, S., Slater, T., Spada, G., Sutterley, T., Talpe, M., Tarasov, L., Van De Berg, W. J., Van Der Wal, W., Van Wessem, M., Vishwakarma, B. D., Wiese, D., and Wouters, B.: Mass balance of the Antarctic Ice Sheet from 1992 to 2017 , https://doi.org/10.1038/s41586-018-0179-y, 2018.

Stearns, L. A., Smith, B. E., and Hamilton, G. S.: Increased flow speed on a large east antarctic outlet glacier caused by subglacial floods, Nature Geoscience, 1, 827-831, https://doi.org/10.1038/ngeo356, 2008.

Stern, A. A., Dinniman, M. S., Zagorodnov, V., Tyler, S. W., and Holland, D. M.: Intrusion of warm surface water beneath the McMurdo ice shelf, Antarctica, Journal of Geophysical Research: Oceans, 118, 7036-7048, https://doi.org/10.1002/2013JC008842, 2013.

Stewart, C. L., Christoffersen, P., Nicholls, K. W., Williams, M. J., and Dowdeswell, J. A.: Basal melting of Ross Ice Shelf from solar heat absorption in an ice-front polynya, Nature Geoscience, 12, 435-440, https://doi.org/10.1038/s41561-019-0356-0, 2019.

Still, H., Campbell, A., and Hulbe, C.: Mechanical analysis of pinning points in the Ross Ice Shelf, Antarctica, Annals of Glaciology, 60, 32-41, https://doi.org/10.1017/aog.2018.31, 2019.

Suckale, J., Platt, J. D., Perol, T., and Rice, J. R.: Deformation-induced melting in the margins of the West Antarctic ice streams, Journal of Geophysical Research: Earth Surface, 119, 1004-1025, https://doi.org/10.1002/2013JF003008, 2014.

Tinto, K. J., Padman, L., Siddoway, C. S., Springer, S. R., Fricker, H. A., Das, I., Caratori Tontini, F., Porter, D. F., Frearson, N. P., Howard, S. L., Siegfried, M. R., Mosbeux, C., Becker, M. K., Bertinato, C., Boghosian, A., Brady, N., Burton, B. L., Chu, W., Cordero, S. I., Dhakal, T., Dong, L., Gustafson, C. D., Keeshin, S., Locke, C., Lockett, A., O’Brien, G., Spergel, J. J., Starke, S. E., Tankersley, M., Wearing, M. G., and Bell, R. E.: Ross Ice Shelf response to climate driven by the tectonic imprint on seafloor bathymetry, Nature Geoscience, 12 , https://doi.org/10.1038/s41561-019-0370-2, 2019.

Van Der Veen, C., Jezek, K., and Stearns, L.: Shear measurements across the northern margin of Whillans Ice Stream, Journal of Glaciology, 53, 17-29, https://doi.org/10.3189/172756507781833929, 2007.

Van Der Veen, C., Stearns, L., Johnson, J., and Csatho, B.: Flow dynamics of Byrd Glacier, East Antarctica, Journal of Glaciology, 60, 1053-1064, https://doi.org/10.3189/2014JoG14J052, 2014.

Van Der Wel, N., Christoffersen, P., and Bougamont, M.: The influence of subglacial hydrology on the flow of Kamb Ice Stream, West Antarctica, Journal of Geophysical Research: Earth Surface, 118, 97-110, https://doi.org/10.1029/2012JF002570, 2013.

Walker, R. T., Dupont, T. K., Parizek, B. R., and Alley, R. B.: Effects of basal-melting distribution on the retreat of ice-shelf grounding lines,

Geophysical Research Letters, 35, 1-5, https://doi.org/10.1029/2008GL034947, 2008. 
https://doi.org/10.5194/tc-2022-50

Preprint. Discussion started: 3 March 2022

(C) Author(s) 2022. CC BY 4.0 License.

(c) (1)

Winberry, J. P., Anandakrishnan, S., Alley, R. B., Bindschadler, R. A., and King, M. A.: Basal mechanics of ice streams: Insights from the stick-slip motion of Whillans Ice Stream, West Antarctica, Journal of Geophysical Research: Earth Surface, 114, 1-11, https://doi.org/10.1029/2008JF001035, 2009.

Zwally, H., Giovinetto, M., Beckley, M., and Saba, J.: Antarctic and Greenland Drainage Systems, GSFC Cryospheric Sciences Laborator, http://icesat4.gsfc.nasa.gov/cryo_data/ant_grn_drainage_systems.php, 2012. 